\title{
Religion and State in the Perspective of Islamic Thought
}

\author{
Supriyanto \\ Pascasarjana IAIN Surakarta \\ antosupriyanto773@gmail.com
}

\begin{abstract}
The discourse on the relationship between religion and state in Islam has been going on for quite some time since the era of the companions of the Prophet, the scholars from the classical era to the contemporary era. The era of the Companions of the Prophet was represented by the Shia, Khawarij and Mu'tazilah groups who had different views on the relationship between religion and state. The classical era was represented by well-known scholars namely Farabi, Mawardi, Ghazali, Ibn Taymiyah and Ibn Khaldun who also had different perspectives on the relationship between religion and state. Likewise, contemporary Muslim scientists present many religious views on the relationship between religion and state. Therefore, this paper will portray how the views of the three groups, some classical and medieval scholars, to modern-day intellectuals about the relationship between the two historically and by using a comparative critical-analysis approach through the perspective of Islamic thought.
\end{abstract}

Keywords: Religion, State, Perspective, Islamic thought.

\begin{abstract}
Abstrak
Diskursus tentang hubungan agama dan negara dalam Islam telah berlangsung cukup lama sejak era para sahabat Nabi, para ulama era klasik hingga era kontemporer. Era para Sahabat Nabi diwakili oleh golongan Syiah, Khawarij dan Mu'tazilah yang memiliki pandangan berbeda tentang hubungan agama dan negara. Era klasik diwakili oleh para ilmuwan terkenal yaitu Farabi, Mawardi, Ghazali, Ibn Taymiyah dan Ibn Khaldun yang juga mempunyai perspektifyang berbeda tentang hubungan agama dan negara. Begitu pula para ilmuwan muslim kontemporer menampilkan pandangan yang beragama mengenai hubungan agama dan negara. Karena itu, tulisan ini akan memotret bagaimana pandangan ketiga golongan tersebut, sebagian ulama klasik dan abad pertengahan, hingga intelektual era modern tentang hubungan keduanya secara historis dan dengan menggunakan pendekatan analisis-kritis komparatif melalui perspektif pemikiran Islam.
\end{abstract}

Kata kunci: Agama, Negara, Perspektif, Pemikiran Islam.

Received: 15-10-2020; accepted: 30-10-2020; published: 10-12-2020 Citation: Supriyanto, 'Religion and State in The Perspective of Islamic Thought', Mawa'izh: Jurnal Dakwah dan Pengembangan Sosial Kemanusiaan, vol. 11, no. 2 (2020), pp. 141-153. 


\section{A. Pendahuluan}

"To state that Islam is only concerned with spiritual life, without having anything to do with society and the state, is perhaps as far from the reality as stating that Islam has provided a comprehensive and detailed social, economic and political system" Fathi Osman. ${ }^{1}$

There is a very strong collective memory among Muslims, namely in Islam there is a kind of doctrine which reads al Islam huwa al-din wa al-dawlah, ${ }^{2}$ Islam is both religion and power. So that the implications of the relationship between religion and state, between ritual and political aspects, are very closely related, even inseparable. The legal aspect touches all socio-political aspects. From the time of the Prophet Muhammad until now, the memories of Medina - the place where the Prophet began to reap success in preaching and building his society — are very strong. ${ }^{3}$

As a rule, Muslims believe in the holistic nature of Islam. As a tool for understanding life, Islam is often seen as something more than just a religion. Some see it as a "civil society". Others see it as a "comprehensive civilization" system. In fact, some believe it to be "religion and state". More specifically, Islam does not recognize a dividing wall between spiritual and temporal. On the contrary, Islam provides ethical guidance for every aspect of life. ${ }^{4}$

Although Islam is believed to provide guidance for all aspects of life, especially regarding state administration or politics, it turns out that the relationship between religion and state in Islam is very poly interpretable, rich in interpretation. Muslim scientists from the classical era to the present day have not agreed on the exact relationship between religion and state in Islam. When traced further, it turns out that in classical thought schools such as, Shi'ah, Khawarij, or Mu'tazilah, they also have different views on the relationship between religion and state. Therefore, this paper will portray how the views of the three groups, some classical and medieval scholars, to modern-day intellectuals about the relationship between the two historically and by using a comparative critical-analysis approach through the perspective of islamic thought.

\footnotetext{
${ }^{1}$ Extract from Bahtiar Effendy, Islam dan Negara (Jakarta: Paramadina, 1998), p. 1.

2 Regarding this doctrine can be seen in Dale F. Eickelman \& James Piscatori, Ekspresi politik Muslim, trans. Rofik Suhud (Bandung: Mizan, 1998), p. 71-2.

${ }^{3}$ Komaruddin Hidayat, Wahyu di Langit Wahyu di Bumi (Jakarta: Paramadina, 2003), p. 93, 101-2.

${ }^{4}$ Bahtiar Effendy, Teologi Baru Politik Islam (Yogyakarta: Galang Press, 2001), p. 7-8.
} 


\section{B. Political Ijtihad for Syi'ah, Khawarij, and Mu'tazilah}

The core issue regarding the relationship between the state and religion in the perspective of the three schools above is still with a community or state leader. The Shi'ah schools agree that Imamat (leadership) is one of the religious beliefs or pillars and pillars of Islam. Their typical political views are as follows:

First, Imamat does not include matters where the election is left to the people, but the Prophet's obligation to appoint and appoint an Imam with clear decree as a substitute for the object of election by the people. ${ }^{5}$ Second, an imam must be ma'shum, a holy person, protected from committing major or minor sins, and he must not commit a single mistake. Everything that comes from him, whether in the form of words or actions, then that is right.

Third, that Ali was an Imam who had been appointed by the Prophet as an Imam after his death, with a clear text. According to Ibn Khaldun, the text is divided into two: jaliy texts (explicit) such as, "Who makes me a leader (maula), ${ }^{6}$ then also make Ali a leader (maula)". And khafiy text (implicit) is that Ali was sent by the Prophet to recite the letter bara'ah during the Hajj season when the letter was sent. ${ }^{7}$

Fourth, every new priest must be appointed and confirmed by his predecessor's text. Because this office is not justified in its implementation for the people so that it causes an Imam to become an Imam by selecting the Muslims. Fifth, the Shi'ah groups believe that Imamat is the property of Ali's grandchildren only. ${ }^{8}$

Then regarding the political attitudes and views of the Khawarij in general it can be argued that they recognized the validity of the caliphate of Abu Bakr, Umar and Uthman in the first years of his reign and Ali until he accepted the arbitrator's decision.

\footnotetext{
${ }^{5}$ According to Lapidus, the doctrine of Imamat only came from the descendants of Ali which was based on the texts socialized by the seventh Imam of the Shi'ah, namely Ja'far al-Sadiq. Ira M. Lapidus, Sejarah Sosial Umat Islam, trans. Ghufron A. Mas'adi (Jakarta: Grafindo Persada, 1999), p. 178.

${ }^{6}$ According to Musawi there is a clear hadith text, namely, "In fact Ali is part of me and I am part of him. And he is the guardian of every believer since I left ". Syarafuddin Musawi, Isu-Isu Penting Ikhtilaf Sunnah-Syi'ah, trans Mukhlis (Bandung: Mizan, 1998), p. 153; In fact, according to most of the Shi'ah, verse 33 of the letter al-Ahzab is the legitimacy of the text against Ali's leadership. Ali Umar al-Habsyi, Keluarga Suci Nabi Saw (Jakarta: Ilya, 2004), p. 187-90.

${ }^{7}$ Ibn Khaldun, Muqaddimah, trans. Ahmadie Thoha (Jakarta: Pustaka Firdaus, 2005), p. 243-4.

${ }^{8}$ Abu A'la al-Maududi, Khilafah dan Kerajaan, trans. Muhammad al-Baqir (Bandung: Mizan, 1996), p. 272-3.
} 
One of the famous motto of the Khawarij is la hukma illa lillah (there are no decisions or provisions except those of God). ${ }^{9}$ This motto was born based on their belief in the verse: "Whoever does not determine the law by what Allah has sent down, is an infidel" (V. $5: 44) \cdot{ }^{10}$

In terms of the position of Caliph the Khawarij took a very democratic direction. ${ }^{11}$ There are at least two important points regarding this issue. First, the appointment of a caliph will be valid only if it is based on a truly free election conducted by all Muslims without discrimination. A caliph remains in his position as long as he is fair, carries out the law, and is far from mistakes and abuses. If he deviates, he must be removed from office. Second, the position of caliph is not the privilege of certain Arab circles, not the monopoly of the Quraish tribe as held by other groups, nor is it specifically for Arabs by denying other nations, but all nations have the same rights. ${ }^{12}$

Meanwhile, the political conception of Mu'tazilah in general emphasizes that the leader of the country is the choice of the people. According to them, this is based on the text in Surah Al-Hujurat verse 13 which states that "the noblest among us for God are the most devout people". Thus, the right to become caliph is not a privilege for a particular family or tribe. The instructions of the Koran are strengthened by the Prophet's words that we submit to the leader even though he is a black slave from Africa. ${ }^{13}$

When viewed from the modern thought paradigm, the views of Khawarij and Mu'tazilah are universal and objective, but this is not the case with Shi'ah. The Shi'ah were trapped in fanatisicm and the spirit of primordialism. They interpret the Quran and Hadith only to support their school. Borrowing Hasan Hanafi's language, they are trapped in the methodology of defense: Islamic creeds are not used as an argument to strengthen Islam itself but to sustain the interests of their school. ${ }^{14}$

9 Jalaluddin Rakhmat, Islam Aktual (Bandung: Mizan, 1996), p 30.

10 This explanation is described quite extensively in Harun Nasution, Teologi Islam (Jakarta: UI Press, 1986), p. 6-21; also contained in his book, Islam (Jakarata: UI Press, 1986), p. 31.

11 The Khawarij democratic principle is also recognized by the philosopher of this century Majid Fakhry in his book, Islamic Philosophy, Theology and Mysticism (England: Oneworld Publicatins, 2003), p. 12.

12 Abu Zahrah, Aliran Politik \&Aqidah dalam Islam, trans. Abd Rahman Dahlan \& Ahmad Qarib (Jakarta: Logos, 1996), p. 69.

13 Munawir Sjadzali, Islam \& Tata Negara (Jakarta: UI Press, 1993), p. 220.

${ }^{14}$ Hassan Hanafi, Dari Akidah ke Revolusi, trans. Asep Usman Ismail. Et al. (Jakarta: Paramadina, 2003), p. 32-4. 


\section{Views of Classical and Medieval Scholars}

Typically, political scientists who are quite representative of the classical and medieval era include Abi Rabi', Farabi, Mawardi, Ghazali, Ibn Taymiyyah, and Ibn Khaldun. Not much different from previous concepts, the political theories compiled by these classical and medieval scholars are also of greater proportion in discussing issues surrounding leaders.

First, of the six Islamic thinkers, Farabi was the only one who idealized the aspects and instruments of state life ${ }^{15}$, while other thinkers contributed their thoughts with a starting point to the reality of the existing monarchy system, which they each accepted as a system. whose legality is unquestionable. Second, these thinkers were greatly influenced by Islamic creed in formulating their theories, such as the state's goal not only for external needs but also spiritual and internal needs. Almost each of them uses the logic of his own original argument. ${ }^{16}$

Third, Abi Rabi', Ghazali and Ibn Taymiyyah clearly state that the power of the head of state or king is a mandate from God given to His chosen servants. The three thinkers were of the opinion that the caliph was the caliph of God or the shadow of God on earth. Even the power of the caliph, according to Ghazali, is holy, in the sense that it is inviolable. Even though Ibn Taymiyya was not as extreme as Ghazali and supported justice ${ }^{17}$, he had the principle that the existence of a head of state despite being wrongful is better for the people than living without a head of state.

Fourth, it was Mawardi who put forward the idea that the power of the head of state was based on a social contract that gave birth to rights and obligations on the basis

15 Regarding Farabi in sufficient detail, it can be found in Yamani, Antara Al-Farabi \& Khomeini (Bandung: Mizan, 2002).

${ }_{16}$ Abi Rabi 'for example by quoting the verse: And He who made you rulers on earth and exalted some of you over others several levels (Quran 6: 165), to obey the ruler; At the beginning of his treatise, Ibn Taymiyyah made Surah an-Nisa verses 58 \& 59 which advocated obedience to leaders as the basis for his theory. Ibn Taimiyah, Pedoman Islam Bernegara, Firdaus (Jakarta: Bulan Bintang, 1989), p. 9-11; Ghazali has very thick religious content as seen in Al-Iqtishad fi al-I'tiqad; Likewise Ibn Khaldun who revealed the theory of Ahsabiyah fid din; in the end all have a common thread that the leader of the community or the State is a religious command.

17 Regarding the concept of justice, there is a statement by Ibn Taymiyyah which is very well known: "God supports just power even though it is an infidel, and does not support wrongdoing even though it is Islam, and the world will still survive with justice even if it is an infidel, and will not survive injustice even if it is an Islam". Quoted from Nurcholish Madjid, Islam Kerakyatan \& Keindonesiaan (Bandung: Mizan, 1996), p. 20. 
of reciprocity between the king and the people. Mawardi is also the only thinker who thinks that a head of state can be removed from the throne if he is no longer able to rule, whether because of physical, mental and moral reasons, even though he does not show how ${ }^{18}$.

Fifth, meanwhile, Ibn Khaldun admits that it is better to use religious teachings and laws as the basis for state policies and regulations rather than simply being engineered by the human brain. However, he also acknowledged that many countries do not base state policies and regulations on religious teachings and laws, but can also create order and achieve success. Perhaps that is the reason, being objective and scientific, he is recognized by the whole world of modern science as the true father of the social sciences. ${ }^{19}$

In the context of the discourse of the Muslim scientists above, perhaps that is what Hanafi aims at that islamic thought can be an object of psychology, sociology and politics. Specifically, the study of political science on islamic thought is not only to sustain power but also to support the opposition. ${ }^{20}$ But in reality, the meaning of the absolute power of God, in the view of the islamic thought in that era, experienced a metamorphosis of becoming the absolute power of a state leader or sultan. ${ }^{21}$

\section{Views of Contemporary Scientists}

Entering the contemporary era from the late 19th century until today, there are at least three schools of thought that analyze the relationship between religion and state. First, the analysis states that Islam cannot be separated from the state. Although they occupy different spaces, Islam and the state are organically linked. They idealize to the

\footnotetext{
${ }^{18}$ Sjadzali, Islam, p. 108-9.

${ }^{19}$ Nurcholish Madjid Islam Agama Peradaban (Jakarta: Paramadina, 2000), p. 136.

${ }^{20}$ Hanafi, Dari Akidah, p. 4.

21 Ibid., p. 20.
} 
past, during the Prophet and Khulafa Rashidun. Rashid Rida, Sayyid Qutb with his Ikhwan and Abu al-A'la al-Maududi represented the group. ${ }^{22}$

Generally they believe in the holistic nature of Islam based on the verse, "And We have sent down the Holy Scriptures to explain all things" (V. 16:89). In Qomaruddin Khan's perspective, this is a wrong view. The verse intends to explain that the Quran contains an explanation of every aspect of moral guidance and not an explanation of all objects of life. The Quran is not an inventory of public knowledge. ${ }^{23}$

Second, the analysis which confirms that religion and state are separate and cannot be reconciled. This model emphasizes that all public affairs must be regulated rationally and secularly, while religion is considered to be in the private domain. Here, religion cannot interfere legally or formally in the political process. Hence there is no Islamic political system and the Prophet of the past era did not have the slightest political function. This concept was initiated by Ali Abd al-Raziq who also based on the Quran and the Prophet's Hadith.

However, it is too much to deny the political function of the Prophet in Medina who was able to display spiritual values and also engage in worldly politics. ${ }^{24}$ Armstrong clearly stated that Muhammad was working on a completely new political solution for his people in the seventh century. ${ }^{25}$ However, what Armstrong read was not a rigid political concept, namely wanting to establish an Islamic state. However, how to socialize the values of Islamic principles to a level of government that is not only useful for Muslims an sich but also for other non-Muslim communities, as exemplified by Muhammad in the past.

Finally, there is a view that does not agree with the first and second groups above, but believes that Islam has a set of principles and values regarding social life, including

22 These figures are very familiar with naqli arguments. For example, Mawdudi uses the verse: "authority belongs only to God. He commands that you worship only Him. That is the true religion "(Qs 12 : 40), to show Allah's absolute sovereignty in the territory of the country. Abul A'la Al-Maududi, Sistem Politik Islam, trans. Asep Hikmat (Bandung "Mizan, 1995), p. 157.

${ }^{23}$ Qomaruddin Khan, Tentang Teori Politik Islam, trans. Taufik Adnan Amal (Bandung: Pustaka, 1987), p. 92.

4.

${ }^{24}$ Karen Armstrong, Muhammadi the Prophet (San Francisco: Harper Collins, 1993), p. 51-2; p. 261-

${ }^{25}$ Karen Armstrong, History of God (New york: Ballantine Books, 1993), p. 140. 
the state. This view is represented by the main character, Mohammad Husain Haikal. ${ }^{26}$ The third school is still motivated by religious beliefs. Political or governmental concepts must be Islamic in character, in the sense of voicing Islamic values and principles even though they are not labeled as Islamic. ${ }^{27} \mathrm{Up}$ to this point, contemporary thinkers' political or state concepts are still a consequence of their Islamic beliefs (faith or creed).

\section{E. Critical Review: Comparison of Political and Siyasah Concepts}

Most Muslim thinkers interpret the meaning of politics that comes from the historical experience of Western nations into the term siyasah. If traced etymologically, the word "politics" clearly has a very different meaning from the word "siyasah". Politics, in the history of Greek experience, comes from the word polis, which means a civilized city. While siasah comes from the verb sasa-yasusu-siyasatan ${ }^{28}$ which means more or less "to herd livestock".

In modern discourse, if politics is related to a principle of managing urban life through a steady and impersonal rule or law, then siasah is related to something more concrete and personal: animal grazing. ${ }^{29}$ Furthermore, the word siyasah, according to $\mathrm{Al}$ Jabiry, has a correlation with the term ra'i which comes from the words of the Prophet: each of you is a shepherd and each of you will be held accountable for each of his shepherds.

A leader is thus also described as a $r a^{\prime} i$ or shepherd. The implication of the meanings of siyasah and $r a^{\prime} i$ makes the Islamic discourse on the management of public life revolve more around the personal piety of ra'i or leaders and ra'iyyah or the people they lead. As a consequence, Muslim rulers often manipulate their power by giving a religious aura, so that the ruler can gain additional legitimacy and religious authority

${ }^{26}$ Regarding Islamic political currents, this is in Mun'im A. Sirry, Membendung Militansi Agama (Jakarta: Erlangga, 2003), p. 76-78; IAIN Jakarta PUSLIT Team, Pendidikan Kewarganegaraan: Demokrasi, HAM dan Masyarakat Madani (Jakarta: IAIN Press, 2000), p. 128.

27 Oliver Leamen, A Brief Introduction to Islamic Philosophy (Cambridge: Polity Press, 1999), p.126.

28 The word also means to care for or teach (horse), rule (the people), and can also be tactics, government, or politics. Mahmud Yunus, Kamus Arab-Indonesia (Jakarta: Hidakarya Agung, 1990), p. 184.

${ }^{29}$ Regarding the political language of Islam such as jihad, kafir, umma, din, dawla, khalifa, and including siasah, it is described in Bernard Lewis, The Politic Language of Islam (Chicago \& London: The University of Chicago Press, 1991), p. 11-9. 
which is often considered sacred by ordinary people. ${ }^{30}$ The phenomenon of power in the classical and medieval era is evidence of this deviation.

The speculation of Islamic political philosophy shoots more on this aspect of individual piety, rather than how to find a model for the system that governs the members who live in a polis. That is the reason why most Muslim political initiators are still trapped in the monarchy system and there is no speculation about other forms of government, such as oligarchy, aristocracy, theocracy or democracy ${ }^{31}$. As a result, the smallest political unit in the siasah concept is the person, either ra'i (shepherd) or ra'iyyah (shepherd). Meanwhile, in the political concept, the smallest unit is a policy or city. More precisely: the policy as a forum for the political community or the public. ${ }^{32}$

In addition, in the Islamic tradition, citizenship did not develop. Even in Arabic, Persian and Turkish there is no word that can accurately represent the word citizen. The word commonly used in Arabic only means the population (sukan) and people (ra'iyyah) which are then Indonesianized to become the people. The word does not represent the word citizen which comes from the word civis which means someone who participates in government political policy matters. The word citizen does not exist in Arabic due to the unfamiliar thought or idea that citizens participate in political policies. ${ }^{33}$

Perhaps that is the reason why the democracy that was tried in Muslim countries from the half of the 20th century until today has failed. This is due to the weak political culture in these countries. Based on the 2001-2002 Freedom House research report index, it was found that during the last 25 years 48 Muslim countries in the world generally failed to establish democratic political systems. Meanwhile, non-Muslim countries in Asia, Africa, Latin America, the former Soviet Union and Eastern Europe generally moved quickly to become democratic. ${ }^{34}$

${ }^{30}$ Azyumardi Azra, Pergolakan Politik Islam (Jakarta: Paramadina, 1996), p. 230.

${ }^{31}$ Here, to be honest, Aristotle's political theory is still much richer. If Muslim scientists only present a system: monarchy, Aristotle offers six forms: monarchy, aristocracy, moderate democracy, tyranny, oligarchy, and extreme democracy. Henry J. Schmandt, Filsafat Politik, trans. Ahmad Baidlowi \& Imam Baehaqi (Yogyakarta: Student Library, 2005), p. 98-104.

32 Regarding the difference in political meaning \& siyasah, this is more widely discussed in Ulil Abshar-Abdalla, Membakar Rumah Tuhan (Bandung: Rosdakarya, 2000), p. 3-14.

${ }^{33}$ Mun'im A. Sirry, Dilema Islam Dilema Demokrasi (Jakarta: Gugus Press, 2002), p. 7-8.

${ }^{34}$ Ibid. h. xv, 33-4. 
Therefore, the main task in order to make democracy work, political ijtihad must shift from attention to an sich ruler to efforts to actively participate in the Muslim community. Concretely: not only having the right to vote, the right to think freely, to express, to assemble, express opinions, associate, organize and establish parties, but also must have the courage to criticize, control, supervise, build opposition, and even bring down deviant rulers. Finally, if you follow one of Hanafi's readings on the object of islamic thought, namely the obligatory form (obligatory al-wujud), then the meaning must be manifested not only in the level of moral and historical conceptions, but also in the constellation of the ideal social and political structure in concrete here, today, in the future. ${ }^{35}$

\section{F. Closing Remarks}

From the various explanations above, at least some conclusions can be drawn. First, there is no single or monolithic view and majority agreement regarding the relationship between religion and state. From the era of companion to the contemporary era, each of them had their own arguments which were heavily influenced by their religious doctrines.

Second, most of the classical and medieval Muslim political scientists were still preoccupied with the project of a leader figure in the concept of the relationship between religion and the state that they formulated. Moreover, the majority of them were still based on the reality at that time that supported the monarchy system without the slightest reserve. ${ }^{36}$

Third, the development of the discourse on the relationship between religion and state began in the contemporary era with three perspectives offered. It would be inappropriate to say that the Koran and the Sunnah clearly define an Islamic political system as it would be a bit excessive if Islam does not provide moral guidelines for the operation of the political system in a country. It is not an exaggeration to say that Islam does not necessarily offer a political system, but in it there is a set of values and ethics

${ }^{35}$ Hanafi, Dari Akidah, p. 223.

${ }^{36}$ Abi Rabi 'who presented his political work to Mu'tashim as the eighth Abasiyah caliph is the most appropriate example of this phenomenon. Sjadzali, Islam, p. 42. 
that can be used as a reference for state and political life in accordance with individual conditions.

Finally, it must be admitted that etymologically and historically, Islam has not or has not initiated the concepts of a democratic state or political life as developed by Western or European scientists. The concept of democratic politics gives the public the right to vote at large to express opinions, associate, criticize, control, build opposition, and even bring down deviant rulers. Maybe the more social concepts that should be prioritized and initiated, to balance the individual concepts that have been so dominant in coloring the discourse of the relationship between religion and state among Muslim scientists, hopefully. 


\section{Bibliography}

Abdalla, Ulil Abshar. Membakar Rumah Tuhan. Bandung: Rosdakarya, 2000.

Al-Habsyi, Ali Umar. Keluarga Suci Nabi Saw. Jakarta: Ilya, 2004.

Al-Maududi, Abu A'la. Khilafah dan Kerajaan, trans. Muhammad al-Baqir. Bandung: Mizan, 1996.

Al-Maududi, Abul A'la. Sistem Politik Islam, trans. Asep Hikmat. Bandung "Mizan, 1995.

Armstrong, Karen. Muhammadi the Prophet. San Francisco: Harper Collins, 1993. . History of God. New york: Ballantine Books, 1993.

Azra, Azyumardi. Pergolakan Politik Islam. Jakarta: Paramadina, 1996.

Effendy, Bahtiar. Islam dan Negara. Jakarta: Paramadina, 1998.

Teologi Baru Politik Islam. Yogyakarta: Galang Press, 2001.

Eickelman, Dale F. \& James Piscatori. Ekspresi politik Muslim, trans. Rofik Suhud. Bandung: Mizan, 1998.

Fakhr, Majid. Islamic Philosophy, Theology and Mysticism. England: Oneworld Publicatins, 2003.

Hanafi, Hassan. Dari Akidah ke Revolusi, trans. Asep Usman Ismail. Et al. Jakarta: Paramadina, 2003.

Nasution, Harun. Teologi Islam. Jakarta: UI Press, 1986. Islam. Jakarata: UI Press, 1986.

Hidayat, Komaruddin. Wahyu di Langit Wahyu di Bumi. Jakarta: Paramadina, 2003.

IAIN Jakarta PUSLIT Team. Pendidikan Kewarganegaraan: Demokrasi, HAM dan Masyarakat Madani. Jakarta: IAIN Press, 2000.

Khaldun, Ibn. Muqaddimah, trans. Ahmadie Thoha. Jakarta: Pustaka Firdaus, 2005.

Khan, Qomaruddin. Tentang Teori Politik Islam, trans. Taufik Adnan Amal. Bandung: Pustaka, 1987.

Lapidus, Ira M. Sejarah Sosial Umat Islam, trans. Ghufron A. Mas'adi. Jakarta: Grafindo Persada, 1999.

Leamen, Oliver. A Brief Introduction to Islamic Philosophy. Cambridge: Polity Press, 1999.

Lewis, Bernard. The Politic Language of Islam. Chicago \& London: The University of Chicago Press, 1991.

Madjid, Nurcholish. Islam Kerakyatan \& Keindonesiaan. Bandung: Mizan, 1996. Islam Agama Peradaban. Jakarta: Paramadina, 2000. 
Musawi, Syarafuddin. Isu-Isu Penting Ikhtilaf Sunnah-Syi'ah, trans Mukhlis. Bandung: Mizan, 1998.

Rakhmat, Jalaluddin. Islam Aktual. Bandung: Mizan, 1996.

Schmandt, Henry J. Filsafat Politik, trans. Ahmad Baidlowi \& Imam Baehaqi. Yogyakarta: Student Library, 2005.

Sirry, Mun'im A. Dilema Islam Dilema Demokrasi. Jakarta: Gugus Press, 2002. . Membendung Militansi Agama. Jakarta: Erlangga, 2003.

Sjadzali, Munawir. Islam \& Tata Negara. Jakarta: UI Press, 1993.

Taimiyah, Ibn. Pedoman Islam Bernegara, trans. Firdaus. Jakarta: Bulan Bintang, 1989.

Yamani. Antara Al-Farabi \& Khomeini. Bandung: Mizan, 2002.

Yunus, Mahmud. Kamus Arab-Indonesia. Jakarta: Hidakarya Agung, 1990.

Zahrah, Abu. Aliran Politik \&Aqidah dalam Islam, trans. Abd Rahman Dahlan \& Ahmad Qarib. Jakarta: Logos, 1996. 